\title{
PERBEDAAN KECEMASAN DALAM MENGHADAPI MENOPAUSE ANTARA IBU BEKERJA DENGAN IBU TIDAK BEKERJA
}

\author{
Dwi Nastiti \\ Fakultas Psikologi Universitas Muhammadiyah Sidoarjo \\ email: nastitidwi19@yahoo.co.id
}

\begin{abstract}
ABSTRAK
Penelitian ini bertujuan untuk mengetahui perbedaan tingkat kecemasan dalam menghadapi menopause antara ibu bekerja dengan ibu tidak bekerja. Penelitian ini dilakukan pada ibu-ibu di kecamatan Balongbendo Kabupaten Sidoarjo dengan jumlah sampel 60 orang ibu. Ibu bekerja yang terbagi menjadi 30 orang itu sedangkan ibu tidak bekerja yang terbagi menjadi 30 orang ibu. Penelitian ini merupakan penelitian kuantitatif, dengan teknik analisis menggunakan uji-t, yaitu untuk mengetahui perbedaan kecemasan dalam menghadapi menopouse antara antara ibu yang bekerja dengan ibu yang tidak bekerja. Untuk mengukur kecemasan dilakukan dengan menggunakan skala kecemasan. Hasil analisis diperoleh nilai $\mathrm{t}=1,959$ dengan $\mathrm{p}=0,055(\mathrm{p}>0,050)$ yang berarti tidak ada perbedaan tingkat kecemasan dalam menghadapi menopause antara ibu yang bekerja dengan ibu yang tidak bekerja diperoleh.
\end{abstract}

Kata Kunci : Kecemacan, Menopause

\section{PENDAHULUAN}

Manusia diciptakan oleh Tuhan sebagai dua makhluk dengan jenis kelamin yang berbeda, yaitu lakilaki dan perempuan. Secara kodrati wanita berfungsi sebagai penerus generasi, sedangkan laki-laki sebagai pangkal keturunan. Hubungan biologis antara laki-laki dan perempuan dapat menyebabkan lahirnya seorang anak. Proses terciptanya seorang anak disebabkan karena adanya fungsi biologi dari laki-laki dan perempuan. Meskipun fungsi tersebut berbeda, namun sifatnya saling melengkapi dan saling membutuhkan.

Alat reproduksi laki-laki berbeda dengan alat reproduksi wanita, serta berbeda pula fungsinya. Wanita bertugas mengandung janin dalam kandungan selama 280 hari. 
sel telur yang terdapat dalam rahim seorang wanita disebut sebagai proses pembuahan.

Semua wanita pada dasarnya ingin menikah karena adanya perasaan cinta dan didorong keinginan kuat untuk memperoleh keturunan dari orang yang dicintai dan yang mencintainya. Tujuan dari perkawinan adalah untuk menciptakan sebuah keluarga yang rukun dan harmonis. Hubungan yang ideal dalam sebuah perkawinan menyangkut perasaan kebersatuan, adanya keterlibatan dalam berbagai hal dan saling berbagi diantara keduanya, baik dalam hal fisik, mental, intelektual, emosional, dan bahkan dalam pencarian sumber penghidupan.

Seiring berkembangnya ilmu pengetahuan dan teknologi, maka semakin banyak wanita atau istri yang memutuskan ikut bekerja atau berkarier dengan tujuan membantu menambah penghasilan bagi keluarga dan juga agar kemampuan atau bakat yang dimiliki dapat tersalurkan. Selain itu, setiap istri juga tetap memiliki kewajiban sebagai ibu rumah tangga yang bertugas mengurus suami dan anakanaknya.

Menurut Kartono (dalam Psikologi wanita, 1992:24), selain bertugas sebagai ibu rumah tangga, seorang istri juga berhak mengembangkan bakat, kemampuan dan keterampilannya dengan bekerja di luar rumah. Bagi sebagian wanita, bekerja merupakan pilihan bebas disamping menjadi seorang ibu rumah tangga. Pekerjaan yang digeluti dapat dilatar belakangi oleh motif yang berbeda-beda. Karier atau profesi yang digeluti menuntut adanya keahlian profesional yang telah diperoleh melalui pendidikan.

Hal tersebut diatas, berbeda dengan pengertian ibu rumah tangga menurut konsep tradisional, yaitu wanita yang menghabiskan sebagian besar waktunya untuk memelihara dan merawat suami serta anak anaknya. Fungsi ibu dalam sebuah keluarga adalah merawat, menjaga dan memelihara suami serta anakanaknya. Seorang ibu harus dapat berperan sebagai istri yang setia mendampingi suami dan mampu mengelola kehidupan rumah tangga dengan baik serta dapat menjalankan 
fungsi-fungsi sosialnya dalam kehidupan bermasyarakat.

Menurut Kartono (dalam Psikologi Wanita, 1992:142). Seorang wanita merasa hidupnya belum lengkap tanpa kehadiran seorang anak, dan jika belum mampu melaksanakan perannya sebagai seorang ibu. Lebih lanjut, kemampuan wanita sebagai seorang istri untuk melahirkan anak terkait erat dengan fungsi reproduksi. Namun, menurut Hurlock (dalam Psikologi Perkembangan, 1997:320), setiap wanita harus menyadari bahwa kemampuan melakukan reproduksi lama-kelamaan akan mengalami penurunan, terutama pada usia dewasa madya. Usia dewasa madya dimulai pada usia 40 sampai 60 tahun. Masa tersebut ditandai dengan adanya perubahan jasmani dan rohani, sehingga terjadi proses kemunduran fisik secara bertahap, baik terjadi penurunan kekuatan fisik dan penurunan daya ingat.

Usia dewasa madya merupakan periode yang panjang dalam rentang kehidupan manusia. Perubahan fisik dan psikologis pada masa ini menjadi semakin kelihatan dan menjadi tua seringkali menjadi momok yang menakutkan bagi sebagian wanita. Kekhawatiran ini sering berawal dari pemikiran yang menyatakan bahwa dirinya tidak lagi bugar, tidak sehat dan tidak cantik lagi. Bagi sebagian wanita, kondisi tersebut memang tidak menyenangkan dan bahkan menyakitkan. Salah satu peristiwa dalam rentang usia dewasa madya yang sering membuat wanita merasa cemas atau bahkan takut adalah menopause.

\section{KECEMASAN}

Kecemasan merupakan salah satu unsur emosi yang pernah dialami oleh setiap individu dalam hidupnya karena suatu pengalaman baru yang dialaminya. Kecemasan dapat disebabkan karena emosi, kurang percaya diri, minder, tertekan, frustasi dan sebagainya. Menurut Freud (dalam Suryabrata, 2002), kecemasan berasal dari ketidakmampuan ego untuk menekan impuls dan merupakan sinyal terhadap adanya ancaman bahaya.

Menurut Roger (dalam Suryabrata 2002), kecemasan adalah rasa takut yang disertai adanya 
gangguan-gangguan fisiologis, seperti keringan dingin, pusing, mual dan jantung berdebar.

Kecemasan merupakan hal yang normal yang berguna untuk meningkatkan kewaspadaan dan membantu individu mencapai hasil yang terbaik dari suatu tingkah laku. Kecemasan bukanlah semata-mata suatu masalah kejiwaan, tetapi merupakan suatu pengalaman yang setiap saat dapat terjadi pada siapa saja. Kecemasan berguna sebagai tanda bahaya untuk menghindar dari suatu keadaan yang mengancam.

Menurut Sullivan (dalam Supratiknya, 1993), kecemasan merupakan proses emosi yang bercampur aduk pada saat individu mengalami tekanan perasaan ataupun konflik batin. Kecemasan merupakan suatu kondisi emosional dengan komponen utama rasa takut yang sifatnya tidak jelas. Menurut Kartono (1992:325), kecemasan adalah semacam kegelisahan atau kekhawatiran dan ketakutan sesuatu yang tidak jelas penyebabnya. Gejala-gejala kecemasan dapat berupa rasa khawatir, gugup, cemas, tegang, rasa tidak nyaman, takut, mudah terkejut, berkeringat dan lain sebagainya.

Berdasarkan uraian diatas, dapat disimpulkan bahwa kecemasan merupakan salah satu unsur emosi yang pernah dialami oleh setiap individu dalam hidupnya yang dirasakan sebagai suatu ancaman. Kecemasan dapat disebabkan karena emosi, kurang percaya diri, rendah diri, adanya tekanan, dan frustasi. Kecemasan merupakan pengalaman emosional yang timbul karena adanya ancaman yang tidak jelas penyebabnya, baik yang berasal dari luar maupun yang berasal dari dalam tubuh dan dapat mengganggu keseimbangan hidup bagi individu yang bersangkutan.

$$
\text { Menurut Daradjat }
$$
faktor yang dapat menimbulkan kecemasan adalah akibat tidak terpenuhinya keinginan-keinginan seksual, karena merasa diri dan keadaan fisiknya kurang dan karena pengaruh pendidikan masa kecilnya, atau sering terjadinya frustasi karena tidak tercapainya sesuatu yang diinginkan baik material maupun sosial, dapat menyebabkan 
kecemasan dalam diri seseorang.

Menurut Kartono

(1992),

Selanjutnya dikatakan bahwa

adanya gangguan dalam menghadapi

kecemasan itu dapat pula sebagai

masa menopause pada wanita usia

akibat yang dipelajari atau ditiru, atau dari rasa tidak berdaya, tidak

ada rasa kekeluargaan. Dengan

singkat dapat dikatakan bahwa

kecemasan itu timbul karena

individu tidak mampu menyesuaikan

diri dengan dirinya sendiri, orang

lain dan dengan lingkungan

sekitarnya.

Menurut Wirawan (dalam

Herdayanti, 2001) kecemasan itu

dapat disebabkan oleh faktor-faktor

dari luar maupun faktor-faktor dari

dalam diri individu. Ancaman

bahaya dari luar yang terus menerus

dan sulit dihindari, ketidakadilan

yang dialami terus menerus dan sulit

dihindari, ketidakadilan yang dialami terus menerus dan orang itu tidak berdaya merupakan faktor-faktor yang menyebabkan kecemasan yang berasal dari luar diri individu. Sementara itu faktor dari dalam yang menyebabkan kecemasan adalah perbedaan yang terlalu jauh antara cita-cita atau keinginan dengan kemampuan yang dimiliki. dewasa madya dapat menimbulkan kekecewaan dalam perkawinan maupun dalam pekerjaannya, sehingga dapat menyebabkan timbulnya gangguan kecemasan. Penyebab timbulnya gangguan kecemasan pada istri yang bekerja dapat disebabkan karena para istri lebih memiliki keterlibatan dalam kehidupan perkawinannya bila dibandingkan dari para suaminya (1992).

Umumnya wanita pekerja memiliki konsep diri yang lebih baik, lebih percaya diri dan mempunyai keyakinan dalam menghadapi masa depannya. Sehingga akan lebih bersikap positif dalam menghadapi masa menopause, yaitu dengan cara melakukan banyak aktivitas di kantor, dapat mengalihkan energi dan potensi yang dimilikinya ke arah yang lebih baik, dapat menyibukkan diri ke dalam kegiatan-kegiatan yang positif sehingga tidak memiliki beban mengenai masa menopause yang akan dihadapinya, kalaupun ada 
maka perasaan cemas tersebut akan dapat diatasi dengan baik.

Berbeda dengan wanita yang tidak bekerja dan hanya berprofesi sebagai ibu rumah tangga biasa saja. Dalam menghadapi masa menopause mereka cenderung kurang dapat melakukan penyesuaian diri dengan keadaan tersebut, yang tidak jarang dapat mempengaruhi keseimbangan psikologisnya (Sadli, 1992). Simptom-simptom psikologis yang sering muncul pada masa menopause ini antara lain dapat berupa depresi, mudah tersinggung, menjadi mudah marah, mudah curiga, diliputi banyak kecemasan, dan juga mengalami gangguan sulit tidur (Kartono, 1992).

\section{HASIL DAN PEMBAHASAN}

Hasil analisis nilai $\mathrm{t}=1,959$ dengan $\mathrm{P}=0,055(\mathrm{P}>0,050)$ artinya tidak signifikan. Hasil penelitian tersebut menunjukkan bahwa tidak ada perbedaan tingkat kecemasan dalam menghadapi menopause antara ibu bekerja dengan ibu tidak bekerja, dan hipotesis penelitian yang menyatakan ada perbedaan tingkat kecemasan pada wanita usia dewasa madya dalam menghadapi menopause antara ibu bekerja dengan ibu tidak bekerja ditolak.

Menurut pendapat Wirawan (dalam Hendayanti, 2001) yang mengatakan bahwa kecemasan itu dapat disebabkan faktor-faktor dari luar maupun faktor-faktor dari dalam dri individu. Ancaman itu bahaya dari luar yang terus menerus dm sulit dihindari, ketidakadilan yang dialami terns menerus dan orang itu tidak berdaya merupakan faktor-faktor dari dalam yang menyebabkan kecemasan adalah menghadapi menopause merupakan kecemasan dari dalam diri individu, karena kecemasan menurut Sarasan dan Spielberger merupakan (dalam Hendayanti, 200) bahwa reaksi terhadap suatu pengalaman yang oleh individu bersangkutan dirasakan sebagai ancaman. Kecemasan ini disebabkan oleh adanya konflik, emosi, kurang percaya diri, tekanan, frustasi dan sebagainya.

Selain itu termasuk hal-hal yang bersifat psikologi adalah mengenai konsep diri. Menurut Burns, (dalam Luniar, 1993) bahwa kecemasan sangat dipengaruhi oleh adanya kualitas konsep diri. Hal 
tersebut dikarenakan pada wanita yang menghadapi menopause akan merasa kehilangan tanda kewanitaannya, kehilangan perhatian dari suami dan anak-anak clan merasa kesepian. Namun demikian tidak semua wanita merasakan kecemasan menghadapi menopause. Ada sebagian wanita menganggap bahwa menopause merupakan hal yang wajar yang tidak perlu dicemaskan. Hal tersebut tergantung dari konsep diri seseorang yang berkembang dan terbentuk dari keluarga dan pengalaman yang dipexoleh sepanjang rentang kehidupan melalui lingkungan dimana orang tersebut berinteraksi akan mempengaruhi kepribadian. Wanita yang mempunyai konsep diri positif, tidak akan merasakan penasaran yang tidak berharga, tidak berguna karena merasa setara dengan orang lain sehingga mampu mengatasi tingkat kecemasan menghadapi menopause. Berbeda dengan wanita yang memiliki konsep diri negatif, mereka merasa sering tidak berguna dan tidak berharga bagi orang laporan sehingga peristiwa menghadapi menopause ini akan menimbulkan perasaan cemas yang berlebihan.

\section{DAFTAR PUSTAKA}
Ahmadi, A. (1991). Psikologi Perkembangan. Penerbit PT. Melton Putra. Jakarta.

Basuki, A. (1987). Kecemasan Yang Mencekam. Penerbit Anda. Jakarta.

Bramantyo. (2002). Kiat Sehat dan Bahagia di Usia Menopause. Penerbit Puspa Swara. Jakarta.

Dahlan, A. (1988). Wanita Menopause. Penerbit PT. Pustaka Antara. Jakarta.

Daradjat, Z. (1990). Kesehatan Mental. Penerbit PT. Gunung Agung. Jakarta.

Faisal. (2001). Raid Tidak Wajar dan Menopause. Penerbit Pustaka Populer Obor. Jakarta.

Gunarsa, S.D. (1982). Psikologi Untuk Keluarga. Penerbit PT. BPK Gunung Mulia. Jakarta.

Hall, Calvin. S. \& Lindzey. (1993). Psikologi Kepribadian. Edisi ke-1. Editor: Supratiknya. Penerbit Kanisius. Yogyakarta.

Hawari, H.D. (1989). Mengenal Kecemasan, Stres dan Depresi. Penerbit Anda. Jakarta.

Hurlock, E.B. (1997). Psikologi Perkembangan: Suatu 
Pendekatan Sepanjang

Rentang Kehidupan. (Alih Bahasa: Istiwidayanti \& Soedjarwo). Penerbit Erlangga, Jakarta.

Kartono. (1992). Psikologi Wanita: Mengenal Wanita Sebagai Ibu dan Nenek. Penerbit Mandar Maju. Bandung.

Kasdu, D. (2002). Kiat Sehat \& Bahagia di Usia Menopause. Penerbit Pustaka Pembangunan Swadaya Nusantara. Jakarta.

Mackenzie, R. (1995). Menopause:

Tuntunan Praktis Untuk Wanita. (Alih Bahasa: Widianto). Penerbit Arcan. Jakarta.

Mappiare, A. (1988). Psikologi Orang Dewasa. Penerbit Rineka Cipta. Jakarta.

Maramis. (1990). Dinamika Perkawinan. Penerbit Airlangga University Press. Surabaya.

Monks, F.J., Knors. (1999). Psikologi Perkembangan: Pengantar dalam Berbagai Bagiannya. (Alih Bahasa: Haditono). Gajah Mada University Press. Yogyakarta.

Nazir, M. (1988). Metode Penelitian. Penerbit Ghalia Indonesia. Jakarta.
Hoffman, L.W. \& Nye, I. (1974). Working Mothers. Bass Inc. California.

Patricia, O. (1994). Menghadapi Masa Menopause Dengan Penuh Kebahagiaan. (Alih Bahasa: Roestiawati). Penerbit Bina Rupa Aksara. Jakarta.

Prasadio, T. (1988). Kecemasan dan Manifestasinya. Penerbit Majalah Psikiatri. Jakarta.

Sadli, S. (1990). Diatas 40 Tahun. Penerbit Sinar Harapan. Jakarta.

Santrock. (1995). Life-Span Development: Perkembangan Masa Hidup. (Alih Bahasa: Achmad Chusairi). Penerbit Erlangga. Jakarta.

Spielberger. (1992). Stress \& Anxiety. (Alih Bahasa: Irwin). Hemisphere Publishing Corporation. London.

Suryabrata, S. (1990). Psikologi Kepribadian. Penerbit PT. Raja Grafindo Persada. Jakarta.

Winarsunu, T. (2002). Statistik Dalam Penelitian Psikologi dan Pendidikan. Penerbit Universitas Muhammadiyah Malang. Malang. 